\title{
Is Plant Growth Influenced by the Electromagnetic Forces that Our Planet is Exposed To?
}

\author{
Fredrik C. Størmer ${ }^{1,3}$ \& Frans E. Wielgolaski ${ }^{2}$ \\ ${ }^{1}$ Norwegian Institute of Public Health, 0403, Oslo, Norway \\ ${ }^{2}$ Department of Biology, University of Oslo, Blindern 0316 Oslo, Norway \\ ${ }^{3}$ Fuglehauggaten 10, 0260 Oslo, Norway \\ Correspondence: Fredrik C. Størmer, Fuglehauggaten 10, 0260 Oslo, Norway. Tel: 47-9226-8576. E-mail: \\ fredrik.c.stormer@gmail.com
}

Received: April 8, 2013 Accepted: June 6, 2014 Online Published: June 24, 2014

doi:10.5539/enrr.v4n3p140 URL: http://dx.doi.org/10.5539/enrr.v4n3p140

\begin{abstract}
The purpose of this short note is to describe a possible link between the electromagnetic forces that our planet is exposed to, and the regulation of plant growth. The plants might be affected through the cryptochrome system that is magnetic sensitive, by an external small magnetic field.
\end{abstract}

Keywords: electromagnetic forces, space, sun, plant growth, magnetism, magnetite, crypotochrome

\section{Introduction}

The Earth's magnetic field is about $50 \mu \mathrm{T}$ but this weak magnetic field might exert an influence on biological molecules and in changes in plant growth and development (Belyavskaya, 2004) and also in animal behavour like birds navigation. It has recently been suggested that magnetite in the presence in dura and pia mater, the membranes that are surrounding the brain of human act as a shield against electromagnetic radiation (Størmer, 2014). Similar has been observed in dolphins, pigeons and sea turtles. An increase in the magnetic field from 33-44 to $500 \mu \mathrm{T}$ enhanced growth inhibition of hypocotyls under blue light in Arabidopsis thaliana when cryptochromes are the mediating photoreceptors (Ahmad et al., 2007). Under red light or in total darkness they did not observe any effects. They also found no hypocotyl inhibition by an increase in the magnetic field using mutants lacking cryptochromes, nor did (Harris et al., 2009) find any effects of blue light. Various effects of magnetism upon plants are given in several reports (Yano et al., 2001; Wang et al., 2011).

\section{Plant Studies}

One way to get information about natural magnetism and plant growth is to study the relationship between cosmic radiation (Størmer, 1955) and various plant decadal variations. Cell division in the cambium layer in trees from boreal and temperature latitudes and altitudes is not constant during the year. This discontinuity causes the appearance of growth rings and also phenological plant recurring development throughout the year, particularly by radiation causing different temperatures e.g. in various parts of 24 hour periods (e.g. Wielgolaski \& Inouye, 2013). Studying the interannual variation in the growth rings formed by Sitka spruce (Picea sitchensis) in northern Britain, it was observed a relationship between growth of trees and the flux density of galactic cosmic variation (Dengel et al., 2009). Good agreement between the time series of tree growth rings and the 11 year solar cycle has been found during the maximum solar activity periods (Prestes et al., 2011). This indicates that there is a connection between the electromagnetic radiation from the sun and the magnetic properties of trees. In a recent phenological long term analysis using Corylus, Betula and other woody and herbaceous plants, there seems to be a decadal variation over 10-12 years (Wielgolaski et al., 2011). One hypothesis may be that there is a link between these decadal variations and the solar cycle periods mentioned above.

\section{Effects of Cosmic Rays and Sun'S Magnetic Field Upon the Atmosphere}

Cosmic rays (high energy particles) arise from space and hit our planet with high speed velocity. They come from various places, including the sun and from extremely distant sources such as radiogalaxies and quasars. It's composition is mostly protons but also some helium. Those particles that penetrate the atmosphere, do not reach 
the Earth's ground, but react with the Earth's atmosphere, producing a large shower of secondary particles. The intensity of galactic cosmic rays is quite small compared with the total radiation from the sun. A proposed mechanism is that the remaining cosmic radiation increases the presence of small particles in the air which contributes to drop formation resulting in cloud appearance and thus influences the global climate (Kristjansson et al., 2008; Svensmark et al., 2009; Brumfiel, 2011). More clouds have a cooling effect upon the atmosphere. The amount of cosmic radiation that hits the Earth's atmosphere will vary with the strength of the Sun's magnetic field. This field and the sun winds shelter us from cosmic radiation because increased sun activity decreases this effect. The ionization produced by cosmic rays in the atmosphere has a cyclic periodic component of period roughly twice the 11 year solar cycle period. Long term variation in the global average surface temperature is found to have similar cycle component (Erlykin et al., 2009).Since experiments with Arabidopsis and other plants show various effects of blue light and magnetism upon plant behavior, cosmic rays could also have an effect upon plant growth.

\section{Magnetite and Plants}

It has been shown that plants contain crystalline magnetite $\left(\mathrm{Fe}_{3} \mathrm{O}_{4}\right)$ (Gajdardziska-Josifovska et al., 2001, McLean et al., 2001), the most powerful magnetic compound in nature. It is the only stable iron oxide that contains $\mathrm{Fe}^{2+}$ and it has been suggested that it is involved in plant memory (Størmer \& Wielgolaski, 2010). The magnetite in plants is possibly synthesized de novo like in bacteria and other organisms, but it has also been reported as direct uptake by plants (Zhu et al., 2008; Wang et al., 2011), and is present in all organisms examined. It has been suggested that memory is stored in magnetite crystals in the neurons of the brain (Størmer \& Laane, 2009; Størmer, 2013) and involved in storage of the information that arrives neocortex (Banaclocha et al., 2010). Magnetite may be a universal memory molecule in all living cells (Størmer, 2010; Størmer et al., 2011). It has recently been demonstrated that magnetic memory can be stored in just 12 iron atoms (Loth et al., 2012). Even if only a few molecules of magnetite are found also in living plant cells, could that be one reason for a connection between solar cycle periods and the decadal variations found e.g. in phenology of various plants?

\section{The Magnetic Field in Relation to the Photoreceptor Cryptochrome, the Light Absorbing Pigment Chlorophyll and Plant Growth}

Higher plants are sensitive to the magnetic field in responses that are linked to the blue light absorbing photoreceptor cryptochrome-dependent signaling pathways (Solov'yov et al., 2007). Cryptochrome transducer signals are important for growth, development, magnetosensitivity and circadian clocks. The light-response mechanism is proposed to result from photoreduction of a protein bound flavin chromophore through intramolecular electron transfer (Ritz et al., 2010). One of the FAD (flavine adenine dinucleotide) intermediates in this process has magnetic properties (Solov'yov et al., 2007, 2012). We suggest that plants generally can be affected through cryptochrome by an external magnetic field even as small as the Earth's magnetic field as observed for Arabidopsis by Ahmad et al. (2007).

A weak magnetic field does often suppress the plant growth process, cell division and differentiation, and induce significant changes at the cellular and subcellular level (Belyavskaya, 2004), in plants e.g. a decline in the content of chlorophyll a and $b$, while the size and relative volume of mitochondria in cells increase. However, in some studies there are found small effects of a weak magnetic field, and we suggest that one reason for that may be a dependency of the amount of magnetite in the cells.

Chlorophyll a is the main light absorbing pigment in plants and it absorbs light throughout the visible part of the spectrum but mostly in the blue and red regions. It is often stated that plants scarcely do not use the part of the spectrum in between because it may be one way to protect against the input of too much energy that can destroy the chlorophyll molecule, particularly if photosynthesis for some reason is inefficient. Exposure to additional electromagnetic forces may be another reason for destruction of plant tissue as well as their DNA. The leaf epidermis may also function as a UV sunscreen.

\section{Concluding Remarks}

The effect of magnetism upon plant growth in the $50 \mu \mathrm{T}$ range is not well documented. An indication of plant effects of variation in the sun activity is to study tree rings and other decadal variations within plants. It would have been surprising if natural selection had not taken advantage of magnetic input to enhance the plants survival as it is described in some bacteria, and in the animal world. The cryptochrome "solution" must have been a successful invention. Since one of the cryptochrome intermediates is magnetic sensitive, it is reasonable to suggest that the effect of these compounds and magnetite are involved in plants maintenance and survival. Different plants may also not respond in a similar manner upon electromagnetic radiation. Our hypothesis has to be further evolved and if possible to be documented. 


\section{References}

Ahmad, M., Galland, P., Ritz, T., Wiltschko, R., \& Wiltschko, W. (2007). Magnetic intensity affects cryptochrome-dependent responses in Arabidopsis thaliana. Planta, 225, 615-624.

Banaclocha, M. A. M., Bókkon, I., \& Banaclocha, H. M. (2010). Long term memory in brain magnetite. Medical Hypotheses, 74, 254-257.

Belyavskaya, N. A. (2004). Biological effects due to weak magnetic field on plants. Advances in Space Research, 34, 1566-1574.

Brumfiel, G. (2011). Cloud formation may be linked to cosmic rays. Online Nature. http:dx.doi.org/10.1038/ news.2011.504.

Dengel, S., Aeby, D., \& Grace, J. (2009). A relationship between galactic cosmic radiation and tree rings. New Phytologist, 184, 545-551.

Erlykin, A. D., Sloan, T., \& Wolfendale, A. W. (2009). Solar activity and the mean global temperature. Environmental Research Letter, 4, 014006.

Gajdardziska-Josifovska, M., McClean, R. G., Schofield, M. A., Sommer, C. V., \& Kean, W. F. (2001). Discovery of nanocrystalline botanical magnetite. European Journal of Mineralogy, 13, 863-870.

Harris, S. R., Henbest, K. B., Maeda, K., Pannell, J. R., Timmel, C. R., Hore, P. J., \& Okamoto, H. (2009). Effect of magnetic fields on cryptochrome-dependent responses in Arabidopsis thaliana. Journal of the Royal Society Interface, 6, 1193-1205.

Kristjánsson, J. E., Stjern, C. W., Stordal, F, Fjǽraa, A. M., Myhre, G., \& Jónasson, K. (2008.) Cosmic rays, $\mathrm{CCN}$ and clouds -a reassessment using MODIS data. Atmospheric Chemistry and Physics Discussions, 8, 13265-13299.

Loth, S., Baumann, S., Lutz, C. P., Eigler, D. M., \& Heinrich, A. J. (2012). Bistability in atomic-scale antiferromagnets. Science, 335, 196-99.

McLean, R. G., Schoefield, M. A., Kean, W. F, Sommer, C. V., Robertson, D. P., Toth, D., \& Gaydardziska-Josifovska, M. (2001). Botanical iron minerals: correlation between nanocrystal structure and modes of biological self-assembly. European Journal of Mineralogy, 13, 1235-1242.

Prestes, A., Rigozo, N. R., Nordemann, D. J. R., Wrasse, C. M., Souza Echer, M. P., Echer, E., ... Rampelotto, P. H. (2011). Sun-earth relationship inferred by tree growth rings in conifers from Severiano De Almeida Southern Brazil. Journal of Atmospheric and Solar-terrestrial Physics, 73, 1587-1593.

Ritz, T., Yoshii, T., Helfrich-Foerster, C., \& Ahmad, M. (2010). Cryptochrome. A photoreceptor with the properties of a magnetoreceptor? Communicative \& Integrative Biology, 3, 24-27.

Solov'yov, I. A., \& Schulten, K. (2012). Reaction kinetics and magnetism of magnetic field effects in cryptochrome. The Journal of Physical Chemistry B, 116, 1089-1099.

Solov'yov, I. A., Chandler, D., \& Schulten, K. (2007). Magnetic field effects in Arabidopsis thaliana cryptochrome-1. Biophysical Journal, 92, 2711-2726.

Størmer, C. (1955). The polar aurora (pp. 375-381). Oxford : Clarendon Press.

Størmer, F. C. (2010). Magnetite: Structure, Properties and Applications. In D. M. Angrove (Ed.), Magnetite, Structure, Properties and Applications (pp. 335-365). Nova Science Publishers, Inc.

Størmer, F. C. (2013). Is memory stored in the brain neurons and is magnetite involved? Medical Hypotheses, $81,1170$.

Størmer, F. C. (2014). Magnetite in pia and dura mater in human brain. A shield against electromagnetic radiation? Medical Hypotheses, 82, 122-123.

Størmer, F. C., \& Laane, C. M. M. (2009). Membrane-bound memory in the neurons? Medical Hypotheses, 73, 462.

Størmer, F. C., \& Wielgolaski, F. E. (2010). Are magnetite and ferritin involved in plant memory? Review Environmental Science Biotechnology, 9, 105-107.

Størmer, F. C., Mysterud, I., \& Slagsvold, T. (2011). Evolution and possible storage of information in a magnetite system of significance for brain development. Medical Hypotheses, 76, 901-904. 
Svensmark, H., Bondo, T., \& Svensmark, J. (2009). Cosmic ray decreases affect atmospheric aerosols and clouds. Geophysical research letters, 36, L15101.

Wang, H., Kou, X., Pei, Z., Xiao, J. Q., Shan, X., \& Xing, B. (2011). Physiological effects of magnetite $\left(\mathrm{Fe}_{3} \mathrm{O}_{4}\right)$ nanoparticles on perennial ryegrass (Lolium perenne L) and pumkin (Cucurbita mixta) plants. Nanotoxicology, 5, 30-42.

Wielgolaski, F. E, Nordli, Ø., Karlsen, S. R., \& O’Neill, B. (2011). Plant phenological variation related to temperature in Norway during the period 1928-1977. International Journal of Biometerology, 55, 819-830.

Wielgolaski, F. E., \& Inouye, D. W. (2013). Phenology at high altitudes. In M.D. Schwartz (Ed.), Phenology: An Integrative Environmental Science (pp. 225-247). http:dx.doi.org/10.1007/978-94-007-6925-0_13

Yano, A., Hidaka, E., Fujiwara, K., \& Limoto, M. (2001). Induction of primary root curvature in radish seedling in a static magnetic field. Bioelectromagnetics, 22, 194-199.

Zhu, H., Han, J., Xiao, J. Q., \& Jin, Y. (2008). Uptake, translocation and accumulation of manufactured iron oxide nanoparticles by pumkin plants. Journal Environmental Monitoring, 10, 713-717.

\section{Copyrights}

Copyright for this article is retained by the author(s), with first publication rights granted to the journal.

This is an open-access article distributed under the terms and conditions of the Creative Commons Attribution license (http://creativecommons.org/licenses/by/3.0/). 